\title{
EFFECT OF USING SUGAR BY - PRODUCTS ON REPRODUCTIV PERFORMANCE OF RAM LAMBS \\ Sallam, A. A. ${ }^{1}$; M.Y. El-Ayek ${ }^{2}$ and A. Senara ${ }^{3}$ \\ 1 Anim. Prod. Res. Institute, Agric. Res. Center. \\ 2 Anim. Prod. Dept., Fac. of Agric., Mansoura Univesity. \\ 3 Dakahlia Company of sugar.
}

\begin{abstract}
To investigate the effect of feeding growing lambs on dried sugar beet pulp (DSBP) or/and dried sugar beet tops (DSBT) as replacement of concentrate feed mixture (CFN) or/and berseem hay $(\mathrm{BH})$ on characteristics of puberty, testosterone profile, scrotal circumference and physical semen characteristics of ram lambs, 24 ram lambs (3/4 Romanof $x \%$ Rahmani) aged 5 mo with $23.46 \mathrm{~kg}$ average body weight were divided into four groups, 6 animals in each. Ram lambs in the $1^{\text {st }}$ group (G1) were fed on ration composed of $50 \% \mathrm{CFM}+50 \% \mathrm{BH}$ (control ration). Ration of the $2^{\text {nd }}, 3^{\text {rd }}$ and $4^{\text {th }}$ groups were as the following: G2: $25 \%$ CFM+25\% DSBP $+50 \% B H$; G3: $25 \% \mathrm{CFM}+25 \% \mathrm{DSBP}+37.5 \% \mathrm{BH}+12.5 \% \mathrm{DSBT}$ and $\mathrm{G} 4: 25 \% \mathrm{CFM}+25 \%$ $\mathrm{DSBP}+25 \% \mathrm{BH}+25 \% \mathrm{DSBT}$. Results show that the dietary treatment had no significant effects on puberty characteristics of ram lambs including age, body weight, scrotal circumference and testosterone concentration at different puberty stages (first mounting, mounting accompanied with erection and mounting accompanied with erection and ejaculation of $1^{\text {st }}$ sperm. The group differences in physical semen characteristics of the $1^{\text {st }}$ ejaculate at puberty including ejaculate volume (EV), percentage of initial motility (IM) and abnormal sperm (AS), sperm cell concentration (SCC), and output of live sperm (LS) and live normal sperm (LNS) were not significant. Only LS percentage in $\mathrm{G} 3$ decreased $(\mathrm{P}<0.05)$ as compared to $\mathrm{G} 1$ (control). Ram lambs in G4 fed mixed of $25 \%$ DSBP+25\% DSBT showed higher $(P<0.05)$ testosterone concentration and lower scrotal circumference than in $\mathrm{G} 1$. During the collection period of semen, EV and percentages of IM and AS were not affected significantly by dietary treatment. However, inclusion of $25 \%$ DSBP (G2) in diet of ram lambs decreased $(\mathrm{P}<0.05)$ percentage of $L S$ and inclusion of $25 \%$ DSBP $25 \%$ DSBT (G4) increased $(P<0.05)$ SCC/ejaculate and LNS output as compared to the control and other treatment groups. Output of TS increased $(P<0.05)$ in $G 4$ than in G2 and G3, but did not differ from that in the control group (G1). It could be concluded that inclusion of $25 \%$ dried sugar beet tops and $25 \%$ dried sugar beet pulp could be used successfully as a replacement of $25 \%$ of berseem hay; and $25 \%$ of concentrate feed mixture in diet of ram lambs.
\end{abstract}

\section{INTRODUCTION}

Sugar beet (Beta vulgaris) has been introduced in Egypt on commercial scale in year 1981/1982 (El-Bilassi, 1987). In 2004/2005 a large area was about 168000 feddans cultivated with sugar beet in Egypt, which produced about 200000 tons of dried sugar beet pulp (DSBP) as a by-product of' sugar beet manufacture. It also produced about 2.1 million tons of fresh sugar beet tops (FSBT) as an agricultural by-product which contained about 200000 tons DM. These by-products were produced from nearly 3444000 tons fresh sugar beet which produced by the Dakahlia Company of sugar at 
Dakahlia Governorate, the Delta Company of Sugar at Kafr El-Shiekh Governorate, the Fayoom Company of Sugar and Abo Korkas Company of Sugar. Also, West Noparia is prepared now to receive large quantities of sugar beet and the expansion in planting the crop in Egypt which may increase the by-product of sugar beet.

In 2004 the Dakahlia Company of sugar received about 964043 tons of fresh sugar beet (FSB) from area of about 52263 feddans cultivated with sugar beet which produced about 62056 tons from DSBP and about 653288 tons of (FSBT) contained about 62.193 tons of DM.

Under Egyptian condition, average of tops yield for the commercial varieties was 12.5 tons/faddan (Improvement of Sugar Beet Production and Utilization, 1990). The residue remaining after extraction of the plant juice, sugar beet pulp (SBP) is an important feed in many areas (Close and Menke, 1986) for both dairy cows (Hemingway et al., 1986; Parkins et al., 1986) and fattening cattle and sheep (Kelly, 1983; McDonald et al., 1985). Usually SBP is sold in the dried state for easy transportation (Mostafa, 2004). DSBP produced in Egypt now is exported for hard currency and also because the Egyptian farmers have not been accustomed to its use as feed for their livestock (Abdelhamid, 1988).

Mahmoud et al. (1998) showed that DSBP could be incorporated in lamb finishing rations and replace up to $50 \%$ of energy source. Moreover, lambs fed on DSBP rations were heavier than those fed the traditional control rations. Also, Mohsen et al. (1999) found that DSBP when corrected for its protein deficiency by adding $0.4 \%$ urea and $0.1 \%$ sulfur could be successfully used as a replacement for traditional concentrate mixture in supplying up to $50 \%$ of the TDN needed for Angora goats. Also nutritive value and performance of growing kids were improved and feed cost increased.

The crude fiber of dried sugar beet pulp is quite digestible and its lignin content is low (El-Ashry et al, 2000; Eweedah, 2001; Saleh et al., 2001). Also, Bendary et al. (1992) and Mohi El-Din (1998) mentioned that large quantities of SBT are produced as an agricultural by-product after harvesting the sugar beet crops. Thus, the availability of using SBT (dried or silage) for livestock as a replacement of traditional high quality roughages such as berseem hay (high price feeds).

On the other hand, there are some problems in using fresh sugar beet tops (FSBT) because it is high in moisture, potassium and oxalic acid content which lead to diarrhea and must be taken into consideration when used in animal feeding and ration formulation (Podkowka, 1983; Bendary et al., 1992). So, drying or ensiling of SBT is a method for conservation which may contribute in solving some of the problems as resource of animal feeding shortage and minimize pollution especially in the summer season (Ali and Darwish, 2001). Moreover, it may offer a reduction of feed cost and minimize quantities of the expensive feedstuffs used in animal feeding (Mohi El-Din, 1998).

The objective of this study was to investigate the effect of feeding growing lambs on dried sugar beet pulp (DSBP) or/and dried sugar beet tops (DSBT) as replacement of concentrate feed mixture or/and berseem hay on 
characteristics of puberty, testosterone profile, scrotal circumference and physical semen characteristics of ram lambs.

\section{MATERIALS AND METHODS}

The experimental work of this study was conducted at Mahlet Mousa Experimental Station, Animal Production Research Institute, Ministry of Agricultural, in cooperation with Animal Production Department, Faculty of Agriculture, Mansoura University and the Dakahlia Company of Sugar, Egypt during the period from July 2005 to February 2006.

\section{Animals and feeding system:}

Twenty four growing ram lambs (3/4 Romanof $x 1 / 4$ Rahmani) with an average age of 5 months and $23.46 \mathrm{~kg}$ average body weight were used in this study. Animals were divided into four groups with respect to their body weight, 6 animals in each. The experimental period lasted for 186 days. The composition of the experimental rations is presented in Table (1).

Table (1): Formulation of the experimental rations:

\begin{tabular}{|l|c|c|c|c|}
\hline \multicolumn{1}{|c|}{ Ingredient } & $\begin{array}{c}\text { Ration I } \\
\text { (control, G1) }\end{array}$ & $\begin{array}{c}\text { Ration 2 } \\
\text { (G2) }\end{array}$ & $\begin{array}{c}\text { Ration 3 } \\
\text { (G3) }\end{array}$ & $\begin{array}{c}\text { Ration 4 } \\
\text { (G4) }\end{array}$ \\
\hline Berseem hay (BH) & 50.00 & 50.00 & 37.50 & 25.00 \\
\hline Concentrate mixture (CM) & 50.00 & 25.00 & 25.00 & 25.00 \\
\hline Dried sugar beet pulp (DSBP) & - & 25.00 & 25.00 & 25.00 \\
\hline Dried sugar beet tops (DSBT) & - & - & 12.5 & 25.00 \\
\hline Total & 100 & 100 & 100 & 100 \\
\hline
\end{tabular}

The concentrate feed mixture (CFM) contained $13 \%$ undecorticated cotton seed meal, $20 \%$ wheat bran, $12 \%$ soybean meal, $25 \%$ yellow corn, $20 \%$ rice bran, $7.5 \%$ molasses, $1 \%$ common salt and $1.5 \%$ limestone.

All rations were given almost in two equal parts at 8.0 a.m. and 4.0 p.m. according to their body weight to cover their requirements according to NRC (1988). Fresh water was available all times. All animals were weighed at the beginning of the experimental and thereafter at biweekly intervals still the end of the experiment. Feed intake was, calculated every two weeks according to the changes in animal body weight.

\section{Preparation of sugar beet by-products:}

The Dakahlia company of sugar, Dakahlia Governorate is producing large quantities of DSBP in pellet form as a by-product of sugar beet industry. Sugar beet tops (SET) were collected from different areas of Dakahlia Governorate after harvesting sugar beet crop and spread on ground over a layer of rice straw, then turning it from time to time (before sunrise and after sun down) till drying (the drying period was about 7 days) then DSBT collected and stored as pills. 
Sallam, A. A. et al.

\section{Puberty detection of ram lambs:}

Ram lambs in all tested groups were subjected to observation to detect changes in sexual behavior, at 10 day-intervals from the beginning of the experimental period till the occurrence of puberty (first successful ejaculate with motile sperm).

To ensure the availability of at least two ewes were synchronized to oestrus by hormonal treatment. Each ewe was given intramuscular injection of $25 \mathrm{mg}$ progesterone (Luton, Misr Co. for Pharma Ind. SAA, Cairo) for five successive days, followed by a single injection of $5 \mathrm{mg}$ estradiol benzoate (Folone Misr Co. for Pharma Ind. SAA, Cairo) $24 \mathrm{~h}$ after the last progesterone injection.

Oestrus was detected for ewes 24-48 h after last hormonal injection (using interact ram). Treatment for oestrous synchronization was planned at a time suitable for the time of libido test. At different stages of puberty (mounting, mounting with erection and mounting with erection and ejaculation of motile sperm), age, body weight, scrotal circumference and testosterone concentration in blood serum.

\section{Testosterone concentration and scrotal circumference:}

Concentration of testosterone was determined in blood serum at 0,2 , $4,6,8,10,12$ and 14 wk of the experimental period as well as at different stages of puberty. Total serum testosterone assay was conducted by radio immune assay method (RIA). Determination- Pontex $335 \mathrm{kit}\left(\mathrm{I}^{125}\right)$ was used to measure the levels of testosterone. Types of testosterone assayed were $(A)$ total testosterone (direct extraction-coated tubes) and (B) free testosterone. It is well known that total testosterone in serum include free testosterone and that bound to 1 pound to sex steroid hormone binding globulin (SHBG) albumin, corticosteroid binding globulin (CBG). According to the instructions of the producing company (Pontex Santa Monica), the solvents used in this assay break the protein binding during extraction process. The standard curve of testosterone ranged between 0.1 and $25.6 \mathrm{ng} / \mathrm{ml}$.

Scrotal circumference measurement was carried out monthly $(1,2,3$, 4,5 and 6 months of the experimental period and during different stages of puberty according to Han et al. (1969).

\section{Semen evaluation:}

Semen of the first ejaculate at puberty) or during the collection period was collected by means of an artificial vagina. Before ejaculation, ram lambs were sexually stimulated by allowing two false mounts followed by 5 minutes restrain. Semen was evaluated for ejaculate volume $(E V)$, percentage of initial motility (IM) (Melros and Laing, 1970), livability (LS) and abnormality (AS) of spermatozoa (Hancock, 1951) and sperm cell concentration (SCC, $\mathrm{x} 10^{9} / \mathrm{ml}$ ) using Neubauer haemocytometer.

Total sperm output (TS $\times 10 \%$ ejaculate) was calculated as sperm cell concentration $/ \mathrm{ml} \times$ ejaculate volume $(\mathrm{ml})$. Live normal sperm output (LNS $\mathrm{x} 10 \%$ ejaculate) was calculated according to the following: Total live normal sperm output/ejaculate $=$ total sperm output $\mathrm{x}$ live sperm (\%) $\mathrm{x}$ normal sperm (\%). 


\section{Statistical analysis:}

Statistical analysis for the obtained data of the stages of puberty and semen characteristics was analyzed by one way ANOVA serum. However, testosterone concentration and scrotal circumference were analyzed by factorial analysis. Duncan multiple range test was used to test the significant differences among means (Duncan, 1955).

\section{RESULTS AND DISCUSSION}

\section{Characteristics of ram lambs at different stages of puberty:}

Data in Table (2) show that the dietary treatment had no significant effects on puberty characteristics of ram lambs including age, body weight, scrotal circumference and testosterone concentration at different puberty stages (first mounting, mounting accompanied with erection and mounting accompanied with erection and ejaculation of $1^{\text {st }}$ sperm.

Regardless the observed changes in all criteria studied at different puberty stages in all groups, the present results indicated that inclusion of DSBP or/and DSBT in diets of ram lambs had no harmful effect of puberty characteristics of ram lambs. The observed gradual increase in testosterone concentration throughout different stages of puberty reaching the maximum level at $1^{\text {st }}$ ejaculation was reported by Saihab et al. (1989) as indicator of increasing testicular parameters between 7 and 10 month of age.

Table (2): Puberty characteristics of ram lambs in tested groups at different stages of puberty.

\begin{tabular}{|c|c|c|c|c|}
\hline \multirow{2}{*}{ Characteristics } & \multicolumn{4}{|c|}{ Tested group } \\
\hline & G1 & G2 & G3 & G4 \\
\hline \multicolumn{5}{|l|}{ I" mounting: } \\
\hline Age (day) & $184.4 \pm 7.07$ & $168 \pm 8.52$ & $185.8 \pm 8.01$ & $182.2 \pm 7.13$ \\
\hline Body weight (kg) & $26.1 \pm 1.86$ & $25.72 \pm 1.62$ & $28.48 \pm 1.09$ & $26.96 \pm 2.67$ \\
\hline Scrotal circumference (cm) & $19.3 \pm 1.88$ & $19.3 \pm 1.50$ & $21.48 \pm 1.31$ & $19.93 \pm 1.87$ \\
\hline Testosterone $(\mathrm{ng} / \mathrm{ml})$ & $0.400 \pm 0.21$ & $0.586 \pm 0.14$ & $0.240 \pm 0.03$ & $0.595 \pm 0.31$ \\
\hline \multicolumn{5}{|l|}{ |s| mounting with erection } \\
\hline Age (day) & $207.8 \pm 9.07$ & $190.8 \pm 10.74$ & $202.2 \pm 10.73$ & $209.3 \pm 7.48$ \\
\hline Body weight $(\mathrm{kg})$ & $28.9 \pm 1.30$ & $29.42 \pm 1.67$ & $30.8 \pm 1.13$ & $31.3 \pm 0.95$ \\
\hline Scrotal circumference $(\mathrm{cm})$ & $22.20 \pm 1.78$ & $21.95 \pm 0.89$ & $23.38 \pm 1.30$ & $23.10 \pm 1.19$ \\
\hline Testosterone $(\mathrm{ng} / \mathrm{ml})$ & $0.832 \pm 0.26$ & $0.797 \pm 0.19$ & $0.580 \pm 0.09$ & $1.048 \pm 0.34$ \\
\hline \multicolumn{5}{|l|}{$1^{\text {st }}$ ejaculation (puberty) } \\
\hline Age (day) & $237.8 \pm 11.24$ & $216.7 \pm 16.07$ & $223.4 \pm 11.72$ & $231.3 \pm 5.38$ \\
\hline Body weight (kg) & $32.5 \pm 0.69$ & $32.56 \pm 2.06$ & $34.02 \pm 0.76$ & $32.97 \pm 2.61$ \\
\hline Scrotal circumference $(\mathrm{cm})$ & $24.88 \pm 0.37$ & $24.48 \pm 0.20$ & $25.96 \pm 0.13$ & $24.82 \pm 0.35$ \\
\hline Testosterone $(\mathrm{ng} / \mathrm{ml})$ & $1.393 \pm 0.12$ & $2.238 \pm 1.18$ & $2.470 \pm 1.19$ & $2.962 \pm 1.19$ \\
\hline
\end{tabular}

All differences are not significant at $P<0.05$.

In accordance with the present results, Mann and Mann (1981) found significant rise in testosterone level at several weeks before start of ejaculation of semen with motile sperm. Similarly, El-Ashry et al. (2000) found that Rahmani lambs reached puberty age between 286-311 days. Ragab et al. (1966) reported that Rahmani lambs reached puberty at 177-456 d when they used 
the sexual behavior and penis development method for determining the age at puberty. Tharwat (1985) found that the age at puberty was $243 d$ when used the testicular histology method for puberty determination in Barki ram lambs. Similar results were reported by Ali and El-Saidy (2003). Also, ElAshry et al. (2000) reported that Rahmani rams lambs reached puberty at about $48.4 \%$ of mature body weight.

Regarding scrotal circumference, ram lambs in G3 reached puberty at $223.4 \mathrm{~d}$ with scrotal circumference of $25.9 \mathrm{~cm}$ and body weight of $34.0 \mathrm{~kg}$. Similarly, All and El-Saidy (2003) found that in ram lambs fed ration in which $\mathrm{BH}$ was replaced by $50 \%$ DSBT, the scrotal circumference was $25.2 \mathrm{~cm}$ at age of $211.8 \mathrm{~d}$. Also, Saihab et al. (1989) reported that body weight at puberty of Awassi rams was $34.4 \mathrm{~kg}$. In this respect, Dyrmundsson (1973) observed that physiological puberty in Clum Forst ram lambs were attained at approximately $35.4 \%$ of the adult body weight

\section{Characteristics of the $1^{\text {st }}$ ejaculate at puberty:}

Results presented in Table (3) revealed insignificant group differences in physical semen characteristics of the $1^{\text {st }}$ ejaculate at puberty including EV, percentage of IM and AS, SCC, and output of LS and LNS. However, only LS percentage in G3 significantly $(P<0.05)$ decreased as compared to G1 (control).

Table (3): Physical semen characteristics of the first ejaculate of ram lambs in tested groups.

\begin{tabular}{|l|c|c|c|c|}
\hline \multirow{2}{*}{\multicolumn{1}{c|}{ Characteristics }} & \multicolumn{4}{c|}{ Tested group } \\
\cline { 2 - 5 } & G1 & G2 & G3 & G4 \\
\hline Ejaculate volume (EV, ml) & $0.75 \pm 0.155$ & $0.66 \pm 0.154$ & $0.66 \pm 0.088$ & $0.53 \pm 0.111$ \\
\hline Initial motility (IM, \%) & $73.6 \pm 3.52$ & $76.6 \pm 5.00$ & $68.3 \pm 5.57$ & $77.5 \pm 2.72$ \\
\hline Live sperm (LS, \%) & $67.7 \pm 0.75^{\mathrm{a}}$ & $65.2 \pm 2.30^{\mathrm{ab}}$ & $59.5 \pm 1.70^{\mathrm{b}}$ & $64.2 \pm 2.27^{\mathrm{ab}}$ \\
\hline Abnormal sperm (AS, \%) & $1.61 \pm 0.83$ & $1.51 \pm 0.24$ & $1.31 \pm 0.18$ & $1.61 \pm 0.49$ \\
\hline SCC $\left(\times 10^{9} /\right.$ ejac.) & $1.21 \pm 0.95$ & $1.00 \pm 0.25$ & $0.86 \pm 0.18$ & $0.85 \pm 0.25$ \\
\hline LS output (x10\%/ejac.) & $0.74 \pm 0.28$ & $0.59 \pm 0.25$ & $0.47 \pm 0.19$ & $0.49 \pm 0.17$ \\
\hline LNS output (x10\% $/$ ejac.) & $0.74 \pm 0.28$ & $0.59 \pm 0.25$ & $0.47 \pm 0.19$ & $0.49 \pm 0.17$ \\
\hline
\end{tabular}

$a$ and $b$ : Means within the same row with different superscripts are significantly different at $P<0.05$. SCC: Sperm cell concentration. LS: Live sperm. LNS: Live normal sperm.

As expected, poor quality semen was produced in association with the $1^{\text {st }}$ ejaculates at puberty in all tested groups. In accordance with the present results, many investigators found that semen quality at puberty was low in quality and reached normal level by advance of age and consequently the complete development of the sex organs (Gabr et al., 1997; Ortize et al., 1997; El-Shamaa, 2002).

\section{Changes in testosterone concentration:}

Results in Table (4) showed significant effect of dietary treatments on overall mean of serum testosterone concentration in ram lambs at different sampling times. Only ram lambs in G4 fed mixed of $25 \%$ DSBP+25\% DSBT showed significantly $(P<0.05)$ higher testosterone concentration than $G 1$, but did not differ from that in G2. However, the differences in testosterone concentration between each of G2 and G3 and G1 were not significant. 
Generally, it is known that the blood serum testosterone concentration was used as an indicator to sexual maturity. Linder (1961) found that concentration of testosterone concentration ranged from 1.7 to $10.5 \mathrm{ng} / 100 \mathrm{ml}$ in spermatic venous blood of rams

Table (4): Means and standard errors (SE) of serum testosterone concentration $(\mathrm{ng} / \mathrm{ml})$ for tested groups at different weeks of the experimental period.

\begin{tabular}{|c|c|c|c|c|}
\hline \multirow{2}{*}{ Period (week) } & \multicolumn{4}{|c|}{ Tested group } \\
\cline { 2 - 5 } & G1 & G2 & G3 & G4 \\
\hline 0 & $0.240 \pm 0.03$ & $0.329 \pm 0.08$ & $0.540 \pm 0.22$ & $0.267 \pm 0.09$ \\
\hline 2 & $0.159 \pm 0.03$ & $0.595 \pm 0.31$ & $0.223 \pm 0.07$ & $0.586 \pm 0.14$ \\
\hline 4 & $0.484 \pm 0.17$ & $0.626 \pm 0.14$ & $0.334 \pm 0.08$ & $1.870 \pm 1.60$ \\
\hline 6 & $0.832 \pm 0.26$ & $1.574 \pm 0.50$ & $1.528 \pm 0.91$ & $1.100 \pm 0.14$ \\
\hline 8 & $1.086 \pm 0.43$ & $0.983 \pm 0.62$ & $0.943 \pm 0.17$ & $2.238 \pm 1.19$ \\
\hline 10 & $0.639 \pm 0.25$ & $0.862 \pm 0.15$ & $1.471 \pm 0.71$ & $3.975 \pm 1.52$ \\
\hline 12 & $0.570 \pm 0.20$ & $1.371 \pm 0.57$ & $1.398 \pm 0.97$ & $2.790 \pm 0.69$ \\
\hline 14 & $1.079 \pm 1.14$ & $3.789 \pm 1.44$ & $1.888 \pm 0.47$ & $2.016 \pm 0.86$ \\
\hline Overall mean & $0.636 \pm 0.104^{\mathrm{b}}$ & $1.266 \pm 0.371^{\mathrm{ab}}$ & $1.041 \pm 0.206^{\mathrm{b}}$ & $1.853 \pm 0.286^{\mathrm{a}}$ \\
\hline
\end{tabular}

$a$ and $b$ Means within the same row or column with different superscripts are significantly different at $P<0.05$.

Changes in scrotal circumference:

Results in Table (5) showed significant effect of dietary treatments on overall mean of scrotal circumference if ram lambs at different sampling times. In an opposite trend to testosterone concentration, ram lambs in G4 fed mixed of $25 \%$ DSBP+25\% DSBT showed significantly $(P<0.05)$ lower scrotal circumference than in G1, but did not differ from that in G3. However, the differences in between each of G2 and G3 and G1 were not significant.

Scrotal circumference was used generally as an indicator for testicular size. The present results are in agreement with those reported by Saihab et al. (1989), who found the highest increase in testicular parameters between 7 and 10 mo of age at $34.1 \mathrm{~kg}$ body weight. Ali and El-Saidy (2003) found that scrotal circumference increased with age advance when (1/2 Finish $\times 1 / 2$ Rahmani) ram lambs were fed rations containing DSBT at rate of 50 and $100 \%$ as a replacement of $\mathrm{BH}$.

Table (5): Means and standard errors (SE) of scrotal circumference $(\mathrm{cm})$ of ram lambs in tested groups during different months of the experimental period.

\begin{tabular}{|c|c|c|c|c|}
\hline \multirow{2}{*}{ Month } & \multicolumn{4}{|c|}{ Tested group } \\
\cline { 2 - 5 } & G1 & G2 & G3 & G4 \\
\hline 1 & $19 \pm 1.40$ & $19 \pm 1.8$ & $19.5 \pm 1.8$ & $18.3 \pm 1.7$ \\
\hline 2 & $23.6 \pm 1.5$ & $22.3 \pm 1.6$ & $22.5 \pm 1.7$ & $21.8 \pm 1.6$ \\
\hline 3 & $25.1 \pm 1.1$ & $25.6 \pm 1.3$ & $24.8 \pm 09$ & $24 \pm 1.3$ \\
\hline 4 & $25.6 \pm 0.4$ & $26.5 \pm 0.8$ & $25.3 \pm 0.8$ & $24.3 \pm 1.1$ \\
\hline 5 & $26.3 \pm 0.5$ & $26.6 \pm 0.7$ & $25.6 \pm 0.7$ & $24.6 \pm 1.0$ \\
\hline 6 & $26.5 \pm 0.4$ & $26.8 \pm 0.4$ & $25.8 \pm 0.9$ & $24.8 \pm 1.2$ \\
\hline Overall mean & $24.3 \pm 0.75^{\mathrm{a}}$ & $24.5 \pm 0.68^{\mathrm{a}}$ & $23.9 \pm 0.60^{\mathrm{ab}}$ & $23.0 \pm 0.64^{\mathrm{b}}$ \\
\hline
\end{tabular}

$a$ and $b$ Means within the same row with different superscripts are significantly different at $\mathbf{P}<0.05$. 
Physical semen characteristics of ram lambs:

Results in Table (6) show that EV and percentages of IM and AS were not affected significantly by dietary treatment. However, inclusion of $25 \%$ DSBP (G2) in diet of ram lambs significantly $(P<0.05)$ decreased percentage of LS and inclusion of 25\% DSBP $25 \%$ DSBT (G4) significantly $(\mathrm{P}<0.05)$ increased $\mathrm{SCC} /$ ejaculate and LNS output as compared to the control and other treatment groups. On the other hand, TS output significantly $(P<0.05)$ increased in $G 4$ than in $G 2$ and $G 3$, but did not differ from that in the control group (G1). Similar ejaculate volumes were reported in rams by Ali and El-Saidy (2003).

Table (6): Physical characteristics of semen collected from ram lambs in the experimental groups.

\begin{tabular}{|c|c|c|c|c|}
\hline \multirow{2}{*}{ Characteristics } & \multicolumn{4}{|c|}{ Tested group } \\
\hline & G1 & G2 & G3 & G4 \\
\hline Ejaculate volume (ml) & $0.85 \pm 0.07$ & $0.80 \pm 0.05$ & $0.82 \pm 0.06$ & $0.84 \pm 0.07$ \\
\hline Initial motility (\%) & $78.7 \pm 6.3$ & $77.2 \pm 4.4$ & $79.4 \pm 4.9$ & $80.3 \pm 1.1$ \\
\hline Live sperm (\%) & $86.9 \pm 7.4^{a}$ & $82.8 \pm 4.8^{b}$ & $87.1 \pm 5.4^{a}$ & $86.6 \pm 0.71^{a}$ \\
\hline Abnormal sperm (\%) & $9.1 \pm 0.58$ & $7.9 \pm 45$ & $9.0 \pm 0.91$ & $9.4 \pm 0.84$ \\
\hline $\operatorname{SCC}\left(\times 10^{9} / \mathrm{ml}\right)$ & $1.66 \pm 0.24^{\mathrm{b}}$ & $1.71 \pm 0.18^{b}$ & $1.67 \pm 0.17^{b}$ & $2.26 \pm 0.18^{\mathrm{a}}$ \\
\hline TS output (x10\%/ejac.) & $1.42 \pm 0.46^{\mathrm{ab}}$ & $1.37 \pm 0.38^{b}$ & $1.35 \pm 0.38^{b}$ & $2.01 \pm 0.72^{\mathrm{a}}$ \\
\hline LNS out put (x10\%/ejac.) & $1.19 \pm 0.43^{b}$ & $1.09 \pm 0.35^{b}$ & $1.14 \pm 0.39^{b}$ & $1.62 \pm 0.54^{a}$ \\
\hline
\end{tabular}

Changes of sperm motility was attributed to testicular and epididmal development. Gabr et al., (1997) and El-Harairy et al. (2002) found that feeding rams on diets containing fish meal or negilla sativa meal increased $(P<0.05)$ percentage of motility of spermatozoa compared with rams in the control group. This means that type of feeding could be affect sperm motility percentage. In disagreement with the present results, Ali and El-Saidy (2003) found that feeding rams on rations containing DSBT at rate of $50 \%$ as a replacement of $\mathrm{BH}$ significantly increased LS percentage compared with the control group and those fed ration containing DSBT at rate of $100 \%$ as replacement of BH. Similar results were reported by Ali and Darwish (2001).

It was suggested that decreasing AS percent may be due to the development and maturation of testicular tissues and epididymal duct. Also, testosterone level known to be necessary for normal spermatogenesis (Mann and ClutwakMann, 1981). Generally, the present AS percentages in all groups are with a range of abnormal sperm cells from 7.5 to $13.17 \%$ as reported by El-Ashry et al. (2000); El-Harairy et al. (2002) and El-Shamaa (2002). Also, El-Badawy (2003) found that AS percent ranged from 8.0 to $12.7 \%$. In accordance with the present results, Ali and El-Saidy (2003) found that feeding rams on rations containing $25 \%$ DSBT as a replacement of $\mathrm{BH}$ resulted in normal sperm concentration $\left(2.05 \times 10^{9} \mathrm{sperm} / \mathrm{ml}\right)$ with insignificant differences comparing with the control group. While, the replacement of all BH by DSBT resulted in significant decrease in SCC. Moreover, Ali and El-Saidy (2003) in mature cross bred rams fed DSBT as a replacement of $\mathrm{BH}$ at rate of $50 \%$. Values of TS output/ejaculate were 
significantly $(\mathrm{P}<0.05)$ higher as replacement of $\mathrm{BH}$ at rate of $100 \%$ than those fed DSBT. However, Bendary et al. (1999) found that no significant differences in TS output $\times 10^{9}$ sperm/ejaculate when Friesian calves fed ration contained DSBT or summer ration contained $\mathrm{CM}$ and $\mathrm{BH}$. In accordance with increasing LNS output in G4, Ali and Darwish (2001) found that LNS output increased by about $18 \%$ for buffalo bulls fed ration contained DSBT as a replacement of $\mathrm{BH}$ at rate of $50 \%$.

\section{CONCLUSION}

From the obtained results, it could be concluded that inclusion of $25 \%$ dried sugar beet tops and $25 \%$ dried sugar beet pulp could be used successfully as a replacement of $25 \%$ of berseem hay and $25 \%$ of concentrate feed mixture in diet of ram lambs.

\section{REFERENCES}

Abdelhamid, A.M. (1988). The use of sugar beet in ruminant feeding. J. Agric. Sci., Mansoura University, 13(2): 710-716.

Ali, M.F. and S.A. Darwish (2001). Productive and reproductive performance of buffalo bulls fed dried sugar beet tops as a replacement of berseem hay. J. Agric. Sci., Mansoura University, 26(6): 3521-3529.

Ali, M.F. and B. El-Saidy (203). The effect of feeding dried sugar beet tops on the productive and reproductive performance of ram lambs. J. Agric. Sci., Mansoura University, 28(8): 5969-5983.

Bendary, M.M.; A.M. Mahmoud; I.S. Koriet and E.M. Mahmoud (1992). Nutritional studies on using sugar beet tops in animal feeding. 2. Chemical composition and nutritive values of sugar beet tops silages made by different methods. Menofiya J. Agric. Res., 17: 109.

Bendary, M.M.; M.M. Mohamed and M.M. Sayeda Ahmed (1999). Nutritional studies on using sugar beet tops in animal feeding. 6- Performance of growing calves fed dried sugar beet tops and its silage. Egyptian Nutr. and Feeds, 2(special issue), 167.

Close, W. and K.H. Menke (1986). Selected topics in animal nutrition. A manual prepared for the $3^{\text {rd }}$ Hobenherin course on animal nutrition in the tropics and semi tropics. $2^{\text {nd }}$ ed. DSE/ZEL, Feldafing, West Germany, p. 144.

Duncan, D.B. (1955). Multiple range and multiple F. test. Biometrics, 11: 10.

Dyrmundson, O.R. (1973). Puberty and early reproductive performance in sheep. II. Ram Lambs. Anim. Breed. Abstr., 41: 419.

El-Ashry, M.A.; Zeba A. Motagally and Y.A. Maareck (2000). Effect of dried sugar beet pulp in dairy buffalo rations on colostrums, milk yield and composition. Egyptian J. Nutrition and Feeds, 3(1): 15-22.

El-Badawy, A.M.M. (2003). Nutritional and physiological studies in ruminant. M.Sc. Thesis, Fac. of Agric., Mansoura Univ. 
El-Bilassi, A.O. (1987). Future expansion in sugar production in Egypt. Sugar cane vs. sugar beet. Conf. of Agric. Sci., Mansoura Univ. on food deficiency overcoming through autonomous efforts in Egypt, 2: 430441.

El-Harairy, M.A.; B.E. El-Saidy; A.E. Abdel-Khalek and F.M. Abou Ammou (2002). Effect of different ruminally undergradable protein sources on reproductive performance of rams. J. Agric. Sci., Mansoura University, 27(7): 4579-4588.

El-Shamaa, I.S. (2002). Onset of puberty, semen production and blood constituents in crossbred male lambs as affected by dietary yeast culture addition. J. Agric. Sci., Mansoura university, 27(7): 4589-4598.

Eweedah, N.M. (2001). Dried sugar beet pulp as a source of energy in sheep rations. Egyptian J. Nutr. and Feeds., 4(Special issue): 241-250.

Gabr, M.G.; A.Z. Fateh-Elbaba; A.M. Yassen and B.E. El-Saidy (1997) Reproductive performance of male Baladi goats and their crosses with imported breeds. I. Sexual development of kids. J. Agric. Sci. Mansoura Univ., 22(8): 2575-2582.

Han, J.; R.H. Foote and G.E. Seidel (1969). Testicular growth and related sperm output in dietary bulls to predict semen quality. J. Anim. Sci., 29: 483.

Hanock, J. L. (1951). A staining trchnique for the study of temperature shock in semen. Nature London 167: 323.

Hemingway, R.G.; J.J. Parkins and J. Fraser (1986). Sugar beet pulp products for dairy cows. Anim. Feed Sci. Technol., 15: 123-127.

Kelly, P. (1983). Sugar beet pulp. A review Anim. Feed. Sci. Technol., 8: 1 18.

Linder, H.R. (1961). Androgens and related compounds in the spermic vein blood of domestic animals. IV. Testicular androgens in the ram boar and stallion. J. Endocrinol., 23: 171.

McDonald, P.; R. A. Edwards and J. P. D. Greenhalg (1985). Animal Nutrition. $3^{\text {rd }} \mathrm{Ed}$, $4^{\text {th }}$ Impression, Longman, London, p: 391

Mahmoud, S.A.; G. El-Santiel and M.F. Ali (1998). Dried sugar beet pulp as a grain replacement in sheep rations. J. Agric. Res., Tanta Univ., 24(2).

Mann, T. and C. Clutwak-Mann (1981). Testis and testicular semen in "male reproductive function and semen". Springer Verlag, New York, 629: 326.

Melarose, D.R. and J.A. Laring (1970). The characteristics of normal semen. Chap. 4. Fertility in the Domestic Animals. Ed. By J.A. Laing Bailliere Tindall and Gassel, London.

Mohi El-Din (1998). Studies on cattle production "nutritional studies on the use of sugar beet byproducts in feeding lactating cows". Ph.D. Thesis, Fac. of Agric., Mansoura University.

Mohsen, M.K.; M.F. Ali and M.I. Basiouni (1999). The effect of partial replacing concentrate mixture by dried sugar beet pulp on performance of growing Angora goats. Prod. of the $7^{\text {th }}$ Sci. Conf. of Animal Nutr. 1921 Oct. El-Arish, Egypt, 309-318.

Mostafa, M.M.M. (2004). Formulating ratios for fast growing lambs. Ph.D. Thesis, Fac. of Agric., Zagazig Univ., Egypt. 
NRC (1988). "Nutrient Requirements of Domestic". Animals Natrient requirements of sheep. $5^{\text {th }}$ Ed. National Academy of Science, National Research Council, Washington DC, USA.

Ortiz, A. R. ; D. M. Halford; M. I. Gelyean; F. A. Scheider and T. K.ridi (1997). Effects of locoweed (oxytropics sericea) on growth, reproduction and serum hormone profiles in young ram. J. Anim. Sci., 75(12): 32293234.

Perkins, J.J.;R.G. Hemingway and J. Fraser (1986). A note on dried molassed sugar beet pulp and unmolassed, pressed sugar-beet pulp as comparative foods for dairy cows. Anim. Prod.. 43: 351.

Podkowka, W. (1983). Sugar beet leaves in animal nutrition. A Review. Zeitschrift "Das Wirtschaftseigene Futter", Band 29, Heft 1, Seite, 37.

Ragab, M.T.; Sharaf El-Din and I.A. Kalil (1966). Sexual behaviour of male lambs as affected by the plane of nutrition. J. Anim. Prod. United Arab Republic, 6: 89.

Saihab, S.A.; M. Zarkawi; M.F. Wardey; M.R. Al-Masry and R. Kassem (1989). Development of testosterone dimensions and size and their relationship to age, body weight and parental size in growing Awassi ram lambs. Assiut Vet. J., 66(1): 20-22.

Saleh, M.S.; N.M. Eweedah; M.F. Ali and M.K. Mohsen (2001). Comparison between dried sugar beet pulp and yellow corn as a source with berseem in ratios of growing lambs. Egyptian J. Nutr. and Feeds, 4(Special issue): $231-239$.

Tharwat, E.E. (1985). Reproductive performance in ram as affected by heat stress. M.Sc. Thesis, Fac. of Agric., Univ., Ain Shams.

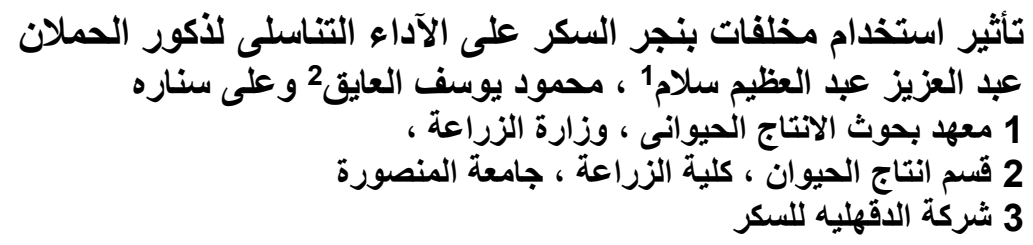

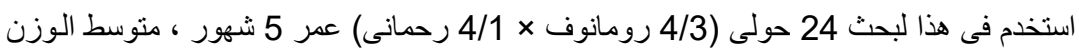

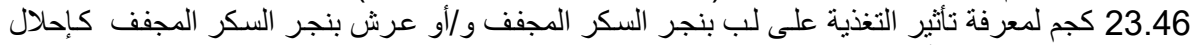

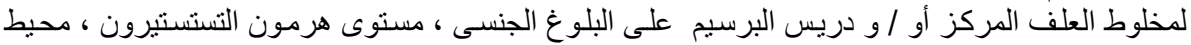

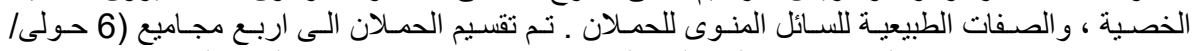

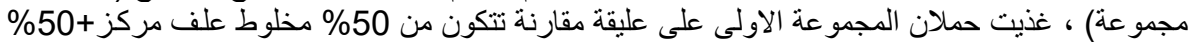

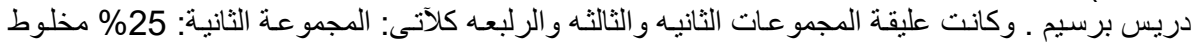

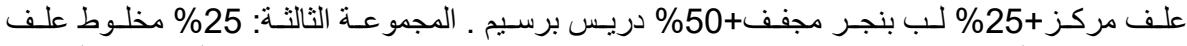

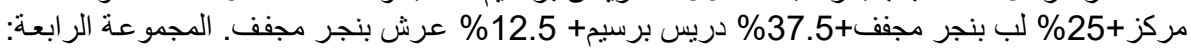

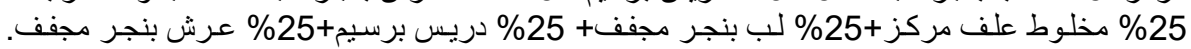

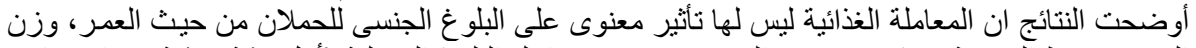

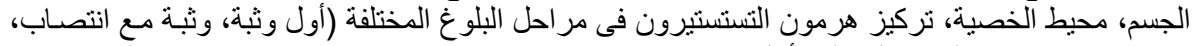

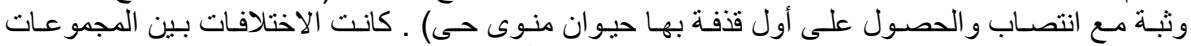

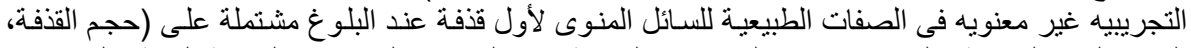

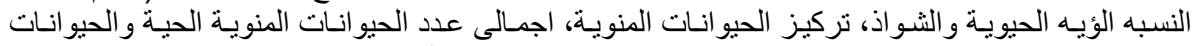

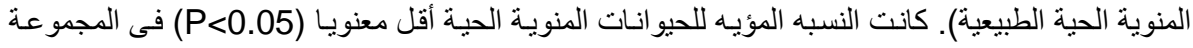




\section{Sallam, A. A. et al.}

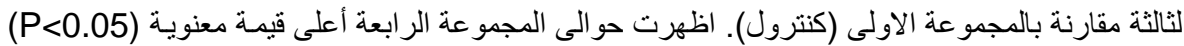

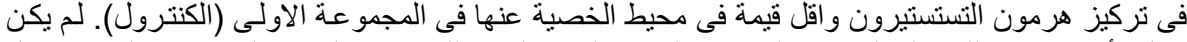

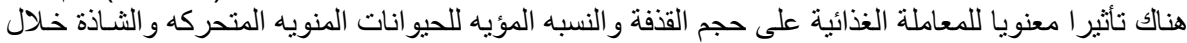

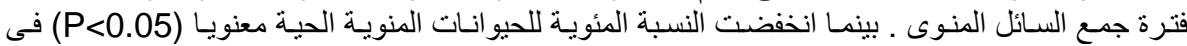

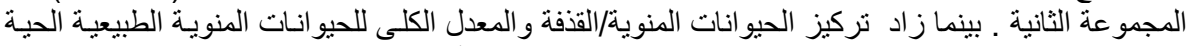

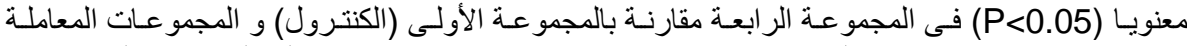

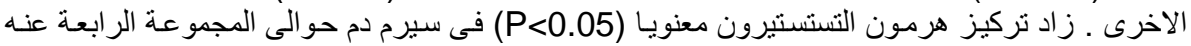

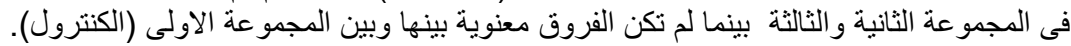

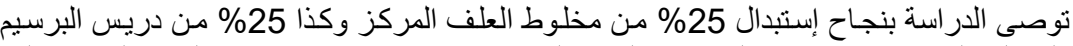

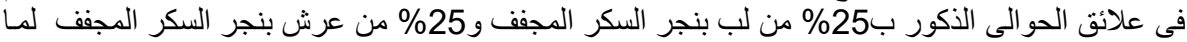
لهما من تأثير على تحسين الاداء التناسلى فى الحملان المستخدمه فى التربيه.

كلية الزراعة - جامعة المنصورة

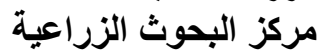

قام بتحكيم البحث

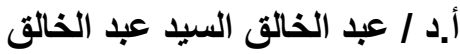
أ.د / فكرى الديد القربى النيد 